\title{
Pembentukan Solusi Awal International Timetabling Competition 2021
}

\author{
Rizal Risnanda Hutama*1, Ahmad Muklason ${ }^{2}$ \\ ${ }^{1,2}$ Departemen Sistem Informasi, FTEIC ITS, Surabaya \\ e-mail: *11r130498@gmail.com, ${ }^{2}$ ahmad.muklason@gmail.com
}

\begin{abstract}
Abstrak
Penjadawalan olahraga merupakan salah satu cabang dari optimasi di riset operasi. Penjadwalan olahraga memiliki berbagai macam batasan yang menantang para peneliti untuk menyelesaikannya. International Timetabling Competition (ITC) 2021 merupakan salah satu kompetisi optimasi yang menyediakan permasalahan penjadwalan olahraga. Permasalahan utama pada ITC 2021 yaitu menentukan jadwal waktu yang tepat untuk sebuah pertandingan. Sebuah jadwal dikatakan dapat digunakan (feasible) apabila tidak melanggar hard constraint yang ada. Pembentukan solusi awal yang feasible saat ini dapat dilakukan dengan algoritma constraint programming atau integer programming. Akan tetapi, kedua algoritma tersebut cukup rumit untuk diimplementasikan. Penelitian ini berfokus pada pembentukan solusi awal yang feasible dengan cara yang mudah untuk diimplementasikan. Cara yang digunakan yaitu dengan mengoptimasi pelanggaran hard constraint menggunakan algoritma Late Acceptance Hill Climbing (LAHC) dan Tabu Search dengan kerangka kerja Hyper-Heuristic yang melibatkan low level heuristic (LLH). Algoritma dijalankan maksimal dengan batasan waktu 6 jam untuk setiap data. Hasil dari optimasi pelanggaran hard constraint menggunakan algoritma LAHC dan tabu search dapat menghasilkan solusi awal yang feasible sebanyak $44.44 \%$ atau 24 dari 54 keseluruhan dataset.
\end{abstract}

Kata kunci-Penjadwalan Olahraga, Late Acceptance Hill Climbing, Tabu Search, HyperHeuristic

\begin{abstract}
Sports scheduling is a branch of optimization in operations research. sports scheduling has various constraints that are challenging for researchers to solve. International Timetabling Competition (ITC) 2021 is an optimization competition that provides sports scheduling problems. The main problem at ITC 2021 is determining the right schedule for a match. A schedule is feasible if it does not violate the existing hard constraints. The construction of a feasible initial solution can now be done using a constraint programming algorithm or an integer programming algorithm. However, both algorithms are quite complicated to implement. This research focuses on establishing a feasible initial solution in a way that is easy to implement. The method used is by optimizing hard constraint violations using the Late Acceptance Hill Climbing (LAHC) algorithm and Tabu Search with a Hyper-Heuristic framework that involves low level heuristics $(L L H)$. The algorithm is run maximum with a time limit of 6 hours for each data. The results of the optimization of hard constraint violations using the LAHC algorithm and tabu search can produce a feasible initial solution of $44.44 \%$ or 24 of the 54 total datasets.
\end{abstract}

Keywords - Sport Scheduling, Late Acceptance Hill Climbing, Tabu Search, Hyper-Heuristic 


\section{PENDAHULUAN}

Pada beberapa tahun terakhir, penjadwalan olahraga menjadi bagian yang seringkali dibahas pada dunia riset operasi khususnya dibidang optimasi permasalahan kombinatorial[1]. Penjadwalan olahraga menjadi pembahasan yang menarik dibidang optimasi karena beberapa faktor[2]. Salah satunya yaitu menjadi tantangan tersendiri karena jumlah tim olahraga berkisar 8 hingga 30, sedangkan kebanyakan algoritma hanya mampu menyelesaikan 8 hingga 20 tim dengan berbagai kesulitan.

International Timetabling Competition (ITC) merupakan sebuah kompetisi yang terkait dengan optimasi penjadwalan. Pada tahun-tahun sebelumnya, ITC menyelenggarakan kompetisi untuk optimasi penjadwalan ujian universitas. Sedangkan pada tahun ini, ITC menyelenggarakan kompetisi untuk optimasi penjadwalan olahraga untuk pertama kalinya[3]. Dalam permasalahan ITC 2021 ini, dibebaskan untuk menggunakan algoritma apapun untuk menyelesaikannya. Akan tetapi, algoritma tersebut harus sama digunakan pada instanceinstance yang lain. Seperti pada permasalahan optimasi yang lainnya, ITC 2021 juga memiliki kompenen hard constraint, soft constraint dan objective function. Dalam permasalahan ini, sebuah solusi dapat digunakan (feasible) apabila tidak terdapat pelanggaran hard constraint.

Hingga saat ini algoritma atau metode yang sering digunakan untuk membentuk solusi awal yaitu constraint programming. Penelitian yang menggunakan constraint programming untuk menyelesaikan permasalahan penjadwalan olahraga dilakukan dengan cara membagi menjadi 2 tahapan yaitu menetapkan partisipan serta jadwal pertandingan dan menetapkan lawan di setiap pertandingan[4]. Penerapan constraint programming juga dilakukan pada permasalahan penjadwalan olahraga round robin[5] dan untuk menentukan jumlah venue yang dibutuhkan[6]. Selain constraint programming, para peneliti sebelumnya juga menggunakan metode integer programming untuk menyelesaikan permasalahan penjadwalan olahraga[7]. Akan tetapi kedua metode tersebut cukup rumit untuk diaplikasikan. Oleh karena itu, dalam penelitian ini mengusulkan sebuah cara yang lebih mudah untuk membentuk solusi awal yang feasible dengan mengoptimasi pelanggaran hard constraint menggunakan algoritma tertentu.

Dalam penelitian ini, algoritma yang digunakan untuk membentuk solusi awal yaitu Late Acceptance Hill Climbing (LAHC) dan Tabu Searh. Algoritma LAHC dinilai cukup mudah implementasinya[8] dan memiliki performa yang cukup bagus[9]. LAHC digunakan sebagai strategi untuk mengurangi pelanggaran hard constraint yang terjadi. Pengurangan hard constraint dilakukan hingga bernilai nol (0) atau tidak terdapat pelanggaran hard constraint. Jika tidak terjadi pelanggaran hard constraint, maka solusi tersebut dikatakan telah feasible sebagai solusi awal. Algoritma LAHC diimplementasikan berdasarkan kerangka kerja HyperHeuristic yang berarti tidak bersinggungan langsung dengan domain permasalahan melainkan bersinggunan dengan low level heuristic (LLH) seperti pada Gambar 1[10]. Sedangkan Tabu Search digunakan sebagai pemilihan LLH terbaik yang akan dijalankan pada setiap iterasinya. 


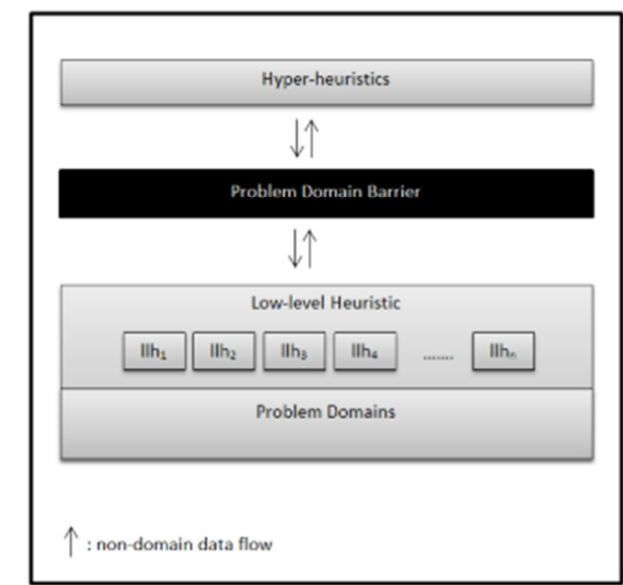

Gambar 1. Kerangka Kerja Hyper-Heuristic

\section{METODE PENELITIAN}

Alur metode yang digunakan pada penelitian ini ditampilkan pada Gambar 2.

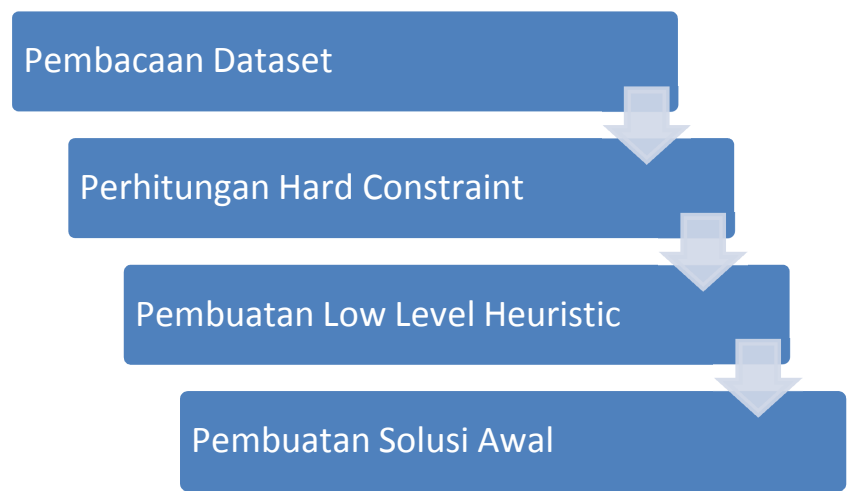

Gambar 2. Alur Metode Penelitian

\section{$2.1 \quad$ Pembacaan Dataset}

Dataset yang diperoleh dari situs ITC 2021 berformat .xml. Oleh karena itu, perlu dilakukan pembacaan dataset dengan tujuan menyimpan dataset tersebut kedalam memori sementara untuk keperluan penelitian ini. Pembacaan dataset dilakukan dengan bantuan SAX Parser. Seluruh data yang dibaca akan disimpan kedalam berbagai bentuk misalnya array, objek, ataupun variabel sesuai dengan kebutuhan penelitian.

\section{2 Perhitungan Hard Constraint}

Dalam permasalahan ITC 2021 memiliki berbagai macam hard constraint yang seluruhnya harus dilakukan perhitungan. Perhitungan hard constraint ini bertujuan untuk mengihitung pelanggaran yang terjadi. Perhitungan hard constraint dilakukan berdasarkan model matematika pada penelitian RobinX[11] yang telah ada dan diperlukan sedikit penyesuaian untuk permasalahan ITC 2021[3]. 


\subsection{Pembuatan Low Level Heuristic}

Low level heuristic (LLH) digunakan untuk menghasilkan solusi lain yang bertujuan untuk menemukan solusi yang memiliki pelanggaran hard constraint lebih rendah. Pembuatan LLH dilakukan berdasarkan penelitian yang sudah ada[12] dan dilakukan sedikit pengembangan. LLH yang digunakan pada penelitian ini yaitu teamSwap, roundSwap, round 3 Swap dan swapHome.

\subsection{Pembuatan Solusi Awal}

Pembuatan solusi awal dilakukan dengan cara optimasi pelanggaran hard constraint menggunakan algoritma late acceptance hill climbing (LAHC). Pembuatan solusi awal dilakukan dengan batasan waktu 6 jam. Jika melebihi 6 jam masih terdapat pelanggaran hard constraint maka dapat dikatakan algoritma yang digunakan gagal dalam membentuk solusi awal. Algoritma LAHC yang diimplementasikan menggunakan panjang fitness array 250. Algoritma LAHC dilakukan sebagai strategi move acceptance dari kandidat solusi yang diperoleh dari proses LLH. Setiap iterasinya LLH yang dipilih ditentukan oleh algoritma tabu search. Panjang tabu search yang digunakan yaitu 3.

\section{HASIL DAN PEMBAHASAN}

Algoritma pembentukan solusi awal dijalankan Hasil pembentukan solusi awal yang dilakukan pada penelitian ini secara keseluruhan ditampilkan pada Tabel 1.

Tabel 1. Hasil Pembentukan Solusi Awal

\begin{tabular}{|c|c|c|c|}
\hline Instance & Hasil & Instance & Hasil \\
\hline Test Instance Demo & Feasible & Middle4 & Belum feasible \\
\hline Test1 & Feasible & Middle5 & Feasible \\
\hline Test2 & Feasible & Middle6 & Belum feasible \\
\hline Test3 & Feasible & Middle7 & Belum feasible \\
\hline Test4 & Belum feasible & Middle8 & Feasible \\
\hline Test5 & Feasible & Middle9 & Feasible \\
\hline Test6 & Belum feasible & Middle10 & Belum feasible \\
\hline Test7 & Belum feasible & Middle11 & Belum feasible \\
\hline Test8 & Belum feasible & Middle12 & Feasible \\
\hline Early1 & Feasible & Middle13 & Belum feasible \\
\hline Early2 & Feasible & Middle14 & Belum feasible \\
\hline Early3 & Belum feasible & Middle15 & Feasible \\
\hline Early4 & Belum feasible & Late1 & Belum feasible \\
\hline Early5 & Belum feasible & Late2 & Belum feasible \\
\hline Early6 & Belum feasible & Late3 & Feasible \\
\hline Early7 & Belum feasible & Late4 & Feasible \\
\hline Early8 & Feasible & Late5 & Feasible \\
\hline Early9 & Feasible & Late6 & Belum feasible \\
\hline Early10 & Belum feasible & Late7 & Belum feasible \\
\hline Early11 & Belum feasible & Late8 & Feasible \\
\hline Early12 & Belum feasible & Late9 & Feasible \\
\hline Early13 & Feasible & Late10 & Belum feasible \\
\hline Early14 & Feasible & Late11 & Feasible \\
\hline Early15 & Belum feasible & Late12 & Belum feasible \\
\hline
\end{tabular}




\begin{tabular}{|c|c|c|c|}
\hline Middle1 & Belum feasible & Late13 & Belum feasible \\
\hline Middle2 & Belum feasible & Late14 & Feasible \\
\hline Middle3 & Belum feasible & Late15 & Feasible \\
\hline
\end{tabular}

Dari hasil tersebut, terdapat 24 dari 54 data yang berhasil ditemukan solusi feasible, dan 30 dari 54 data tidak berhasil ditemukan solusi feasible. Data yang tidak berhasil ditemukan solusi feasible disebabkan karena sangat terbatasnya solusi karena banyaknya batasan yang ada pada data tersebut. Akan tetapi hasil 24 yang berhasil merupakan hasil yang cukup baik mengingat mudahnya mengimplementasikan cara yang digunakan dibandingkan dengan penggunakaan constraint programming atau integer programming.

Jika batasan yang ada pada sebuah data tidak terlalu banyak, solusi yang memungkinkan akan semakin banyak pula. Dengan kemungkinan solusi yang lebih banyak, penggunaan cara optimasi hard constraint dapat dilakukan. Akan tetapi jika batasan pada sangatlah kompleks maka diperlukan cara yang lebih canggih yaitu constraint programming atau integer programming untuk membuat solusi awal.

\section{KESIMPULAN}

Pembentukan solusi awal dengan cara mengoptimasi pelanggaran hard constraint menggunakan algoritma LAHC dan tabu search dapat menghasilkan $44.44 \%$ data yang feasible. Performa tersebut dirasa cukup baik karena mudahnya implementasi cara yang digunakan. Seluruh data dapat ditemukan solusi yang feasible dengan menerapkan algoritma constraint programming atau integer programming sesuai dengan penelitian yang sudah ada sebelumnya.

\section{SARAN}

Penelitian ini hanya menggunakan sebuah algoritma untuk move acceptance strategy sehingga masih banyak algoritma lain yang tidak dilakukan percobaan. Penelitian selanjutnya dapat mengembangkan algoritma dengan kombinasi ataupun penggantian algoritma dengan algoritma yang lebih canggih misalnya population-based algorithm. Selain itu, penelitian selanjutnya juga dapat mencari cara yang mudah selain optimasi hard constraint untuk membentuk solusi awal yang feasible.

\section{UCAPAN TERIMA KASIH}

Penulis mengucapkan terima kasih kepada Bapak Ahmad Muklason selaku dosen dari penulis yang selalu memberikan arahan dalam penelitian ini. 


\section{DAFTAR PUSTAKA}

[1] L. Zeng and S. Mizuno, 2013, "On The Generalized Mirrored Scheme For Double Round Robin Tournaments In Sports Scheduling," Asia-Pacific J. Oper. Res., Vol. 30, No. 3, pp. 1-16, doi: 10.1142/S0217595913400083.

[2] M. A. Trick, 2011, "Sports Scheduling," Springer Optim. Its Appl., Vol. 45, pp. 489508, doi: 10.1007/978-1-4419-1644-0_15.

[3] D. Van Bulck, D. Goossens, J. Beliën, and M. Davari, 2021. "International Timetabling Competition 2021: Sports Timetabling," itc2021.ugent.be.

[4] R. A. Russell and T. L. Urban, 2006, "A Constraint Programming Approach To The Multiple-Venue, Sport-Scheduling Problem,” Comput. Oper. Res., Vol. 33, No. 7, pp. 1895-1906, doi: 10.1016/j.cor.2004.09.029.

[5] M. Henz, "Scheduling A Major College Basketball Conference - Revisited," Oper. Res., Vol. 49, No. 1, pp. 163-168, 2001, doi: 10.1287/opre.49.1.163.11193.

[6] L. H. Su, Y. Chiu, and T. C. E. Cheng, "Sports Tournament Scheduling To Determine The Required Number of Venues Subject To The Minimum Timeslots Under Given Formats," Comput. Ind. Eng., Vol. 65, No. 2, pp. 226-232, 2013, doi: 10.1016/j.cie.2013.02.021.

[7] T. Van Voorhis, "College Basketball Scheduling With Travel Swings," Comput. Ind. Eng., Vol. 48, No. 2, pp. 163-172, 2005, doi: 10.1016/j.cie.2005.01.003.

[8] E. K. Burke and Y. Bykov, 2017, “The Late Acceptance Hill-Climbing Heuristic," Eur. J. Oper. Res., Vol. 258, No. 1, pp. 70-78, doi: 10.1016/j.ejor.2016.07.012.

[9] A. L. Aro Bolaji, A. F. Bamigbola, and P. B. Shola, 2018, "Late Acceptance Hill Climbing Algorithm For Solving Patient Admission Scheduling Problem," KnowledgeBased Syst., vol. 145, no. February, pp. 197-206, doi: 10.1016/j.knosys.2018.01.017.

[10] A. Muklason, 2017. "Solver Penjadwal Ujian Otomatis Dengan Algoritma Maximal Clique dan Hyper-heuristics,” Semin. Nas. Teknol. Informasi, Komun. dan Ind. 9, pp. $18-19$,

[11] D. Van Bulck, D. Goossens, J. Schönberger, and M. Guajardo, 2020, "RobinX: A ThreeField Classification And Unified Data Format For Round-Robin Sports Timetabling," Eur. J. Oper. Res., Vol. 280, No. 2, pp. 568-580, doi: 10.1016/j.ejor.2019.07.023.

[12] T. Januario, S. Urrutia, C. C. Ribeiro, and D. De Werra, 2016, "Edge coloring: A Natural Model For Sports Scheduling," Eur. J. Oper. Res., Vol. 254, No. 1, pp. 1-8, doi: 10.1016/j.ejor.2016.03.038. 